\begin{tabular}{c|c|c}
\hline \hline $\begin{array}{c}\text { Vol. 105: 163-174, 2013 } \\
\text { doi: } 10.3354 / \text { dao02614 }\end{array}$ & $\begin{array}{c}\text { DISEASES OF AQUATIC ORGANISMS } \\
\text { Dis Aquat Org }\end{array}$ & Published July 22 \\
\hline \hline
\end{tabular}

REVIEW

\title{
CyHV-3: the third cyprinid herpesvirus
}

\author{
Michael Gotesman ${ }^{1}$, Julia Kattlun ${ }^{1}$, Sven M. Bergmann' ${ }^{2}$, Mansour El-Matbouli ${ }^{1, *}$ \\ ${ }^{1}$ Clinical Division of Fish Medicine, University of Veterinary Medicine, Vienna, Austria \\ ${ }^{2}$ Friedrich-Loeffler-Institut, Federal Research Institute for Animal Health, Institute of Infectology, \\ Greifswald-Insel Riems, Germany
}

\begin{abstract}
Common carp (including ornamental koi carp) Cyprinus carpio L. are ecologically and economically important freshwater fish in Europe and Asia. C. carpio have recently been endangered by a third cyprinid herpesvirus, known as cyprinid herpesvirus-3 (CyHV-3), the etiological agent of koi herpesvirus disease (KHVD), which causes significant morbidity and mortality in koi and common carp. Clinical and pathological signs include epidermal abrasions, excess mucus production, necrosis of gill and internal organs, and lethargy. KHVD has decimated major carp populations in Israel, Indonesia, Taiwan, Japan, Germany, Canada, and the USA, and has been listed as a notifiable disease in Germany since 2005, and by the World Organisation for Animal Health since 2007. KHVD is exacerbated in aquaculture because of the relatively high host stocking density, and CyHV-3 may be concentrated by filter-feeding aquatic organisms. CyHV-3 is taxonomically grouped within the family Alloherpesviridae, can be propagated in a number of cell lines, and is active at a temperature range of 15 to $28^{\circ} \mathrm{C}$. Three isolates originating from Japan (KHV-J), USA (KHV-U), and Israel (KHV-I) have been sequenced. CyHV-3 has a $295 \mathrm{~kb}$ genome with 156 unique open reading frames and replicates in the cell nucleus, and mature viral particles are 170 to $200 \mathrm{~nm}$ in diameter. CyHV-3 can be detected by multiple PCR-based methods and by enzyme-linked immunosorbent assay. Several modes of immunization have been developed for KHVD; however, fish immunized with either vaccine or wild-type virus may become carriers for CyHV-3. There is no current treatment for KHVD.
\end{abstract}

KEY WORDS: Aquaculture $\cdot \mathrm{KHV} \cdot$ Koi herpesvirus disease $\cdot$ KHVD $\cdot$ Skin hemorrhages $\cdot$ Virus detection $\cdot$ Enzyme-linked immunosorbent assay $\cdot$ ELISA

Resale or republication not permitted without written consent of the publisher

\section{INTRODUCTION}

Fish protein makes up $20 \%$ or more of the total protein consumed in low-income, food-deficient countries, with aquaculture accounting for $46 \%$ of the global food fish supply in 2008; in addition to being a critical form of nutrition, foodfish production through aquaculture is also a major form of employment (FAO 2010). Carp (Cyprinidae) make up $71 \%$ of the global farmed freshwater fish production and are an important source of food in China and India where 70.7 and $15.7 \%$, respectively, of farmed carp are produced. However, cyprinid herpesvirus (CyHV-3), which is the etiological agent of a highly contagious viral disease, koi herpesvirus disease (KHVD), is causing massive damage to the world production of koi and common carp Cyprinus carpio L. The disease has been listed since 2005 in Germany, and since 2007 in England and by the World Organisation of Animal Health (OIE) as a notifiable disease, and has spread to most regions of the world due to the global fish trade and international ornamental koi shows (Pokorova et al. 2005, llouze et al. 2008, FAO 2010). KHVD is characterized by white patches, skin hemorrhages, lethargy, lack of appetite, sunken eyes, enlargement of the spleen and kidney, and gill necrosis (Fig. 1) in infected fish (Hedrick et al. 2005). The virus replicates in gills, intestine, interstitium, 

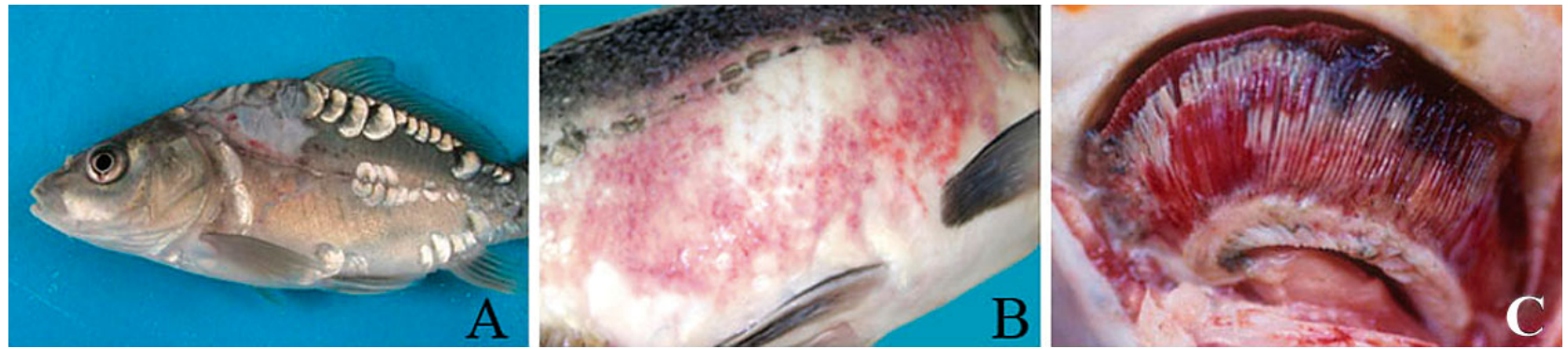

Fig. 1. Cyprinus carpio. Clinical signs of koi herpesvirus disease. (A) Increased mucus production, petechia, enophthalmus. (B) Confluent bleedings in the skin. (C) Severe gill necrosis

liver, brain, and kidney tissues (Pikarsky et al. 2004), and was previously known as carp interstitial nephritis and gill necrosis virus. Because KHVD has become so detrimental to world foodfish production, this review will cover the discovery of KHVD, the spread of CyHV-3, progress in our understanding of the disease and host-pathogen relationship, tools developed to detect the virus, and methods developed to control the disease.

\section{The cyprinid herpesvirus family}

Based on sequence alignment of conserved regions for the DNA polymerase and terminase genes, the cyprinid herpesviruses are closely related to anguillid herpesvirus 1 (AngHV-1) (Waltzek et al. 2009a). CyHV-3 shares 40 conserved genes with AngHV-1 (van Beurden et al. 2010), and according to the International Committee on Taxonomy of Viruses (http://ictvonline.org/), all 3 cyprinid herpesviruses and AngHV-1 are grouped within the genus Cyprinivirus. The first cyprinid herpesvirus, cyprinid herpesvirus-1 (CyHV-1), was isolated in Japan from the papillomatous skin growth on an infected koi and propagated in epithelioma papulosum cyprini (EPC) and fathead minnow (FHM) cell lines at $20^{\circ} \mathrm{C}$ (Sano et al. 1985a), and was described with the dimensions of 113 and $190 \mathrm{~nm}$ for the nucleocapsid and mature enveloped virion respectively (Sano et al. 1985b). Later, a cyprinid herpesvirus was isolated in North America by Hedrick et al. (1990), and was described with the dimensions of 109 and $157 \mathrm{~nm}$ for the nucleocapsid and mature enveloped virion. CyHV-1 is lethal in young fish, and can cause mortality rates up to $97 \%$ (Sano et al. 1991). Although CyHV-1 causes acute growth of papillomas, it is usually non-lethal to adult koi (Calle et al. 1999). Cyprinid herpesvirus-2 (CyHV2) affects mainly goldfish Carassius auratus auratus and has been isolated in EPC and FHM cell lines grown at $20^{\circ} \mathrm{C}$ (Jung \& Miyazaki 1995, Groff et al. 1998), but neither cell line is suitable for serially passaging the virus (Goodwin et al. 2006a). Jeffery et al. (2007) passaged CyHV-2 in a koi fin-1 (KF-1) cell line once, but no cytopathic effect (CPE) was observed on subsequent passages. CyHV-2 has been passaged in a goldfish fin cell line (GF-1) for studies in phylogenetic analysis and detection assays (Waltzek et al. 2005, 2009b). The clinical signs of CyHV-2 infection include lethargy, development of pale skin with white, mucoid, blister-like projections on tissue, and ultimately mortality (Jeffery et al. 2007). Postmortem inspection of CyHV-2 infected goldfish revealed severe necrosis of gills and deterioration of the kidney and liver (Jeffery et al. 2007). CyHV-2 causes herpesviral hematopoietic necrosis in goldfish (Jung \& Miyazaki 1995), and can be detected by PCR (Goodwin et al. 2006a,b). CyHV-2 viral particles are hexagonal, and intranuclear particles have a diameter of $100 \mathrm{~nm}$ with a $50 \mathrm{~nm}$ core (Jeffery et al. 2007). Mature, enveloped virions range from 170 to $220 \mathrm{~nm}$ in size when observed in the cytoplasm and extracellular spaces (Jung \& Miyazaki 1995). Random sampling in goldfish farms has shown that CyHV-2 is highly prevalent in the USA (Goodwin et al. 2009). There are 3 main isolates of the third cyprinid herpesvirus, CyHV-3, one originating in Japan, another in Israel, and another isolated in the US, denoted KHV-J, KHV-I, and KHV-U, respectively.

\section{Taxonomy}

CyHV-3 shares homology to Poxviridae, Iridoviridae, and Nimaviridae proteins involved in synthesis of deoxynucleotide tri-phosphates (dNTPs); however, $\mathrm{CyHV}-3$ is genetically divergent from the aforementioned virus families and is more similar to CyHV-1 and CyHV-2; therefore, CyHV-3 is considered the third cyprinid herpesvirus (Waltzek et al. 2005, Ilouze 
et al. 2006). Protein sequence comparison of helicase, capsid triplex protein, DNA polymerase, and major capsid protein (open reading frame 39: ORF39) confirmed sufficient significant homology for CyHV-3 to be grouped with the other 2 cyprinid herpesviruses in a new order, the Herpesvirales (Waltzek et al. 2005). Based on the genes encoding viral DNA polymerase and the ATPase subunit of terminase, CyHV3 is currently classified together with CyHV-1 and CyHV-2 in the genus Cyprinivirus within the family Alloherpesviridae (Waltzek et al. 2009a, Michel et al. 2010a). The isolates can be differentiated by duplex PCR to detect minor mutations in the coding region between ORF29 and ORF31 (Bigarré et al. 2009). The cloning and subsequent sequencing of the 3 glycoproteins ORF25, ORF65, and ORF 116 detected variation that include specific insertions and deletions among the 3 main KHV isolates (Han et al. 2013).

\section{Early history and worldwide distribution}

CyHV-3 was initially identified by Hedrick et al. (2000) as the causative agent for mass mortality outbreaks in the US and Israel, but may have been detected as early as 1996 in England (Haenen et al. 2004) and 1997 in Germany (Bretzinger et al. 1999). Three CyHV-3 isolates are completely sequenced: accession nos. in the NCBI nucleotide database NC_009127 (DQ177346 [strain I]; DQ657948 [strain U]; and AP008984 [strain J, TUMST1]). Each can be identified based on sequence disparities in different genes. Kurita et al. (2009) grouped the 3 sequenced CyHV-3 isolates as either US/I or J strains based on nucleotide polymorphism in the thymidine kinase (TK) gene; this grouping system was verified by Avarre et al. (2011) tracking disparities in tandem repeats in genetic sequences of 8 different CyHV-3 loci. Some European isolates are similar to isolates from the US and Israel (KHV-U and KHV-I, respectively). Other isolates that may be variants of CyHV-3, which are known as KHV-J, have been detected in Japan, Malaysia, Taiwan, and other East Asian countries (Kurita et al. 2009, Cheng et al. 2011). Recently, based on sequence comparison of glycoproteins, a new variant of KHV was detected in Korea (Han et al. 2013).

\section{Europe}

Researchers in Germany were among the earliest to describe KHVD in koi (Bretzinger et al. 1999). Since then, CyHV-3 has been detected in several farms in Poland, where carp is grown for food (Antychowicz et al. 2005, Bergmann et al. 2006). There are sporadic CyHV-3-positive locations of commercial koi and common carp farms in the Czech Republic (Pokorova et al. 2007). England and Wales have widespread KHVD in carp and koi fisheries, but there are separate carp and koi farms that are free of CyHV-3 (Taylor et al. 2010, 2011). Two cases of KHVD were reported in Ireland, one in 2005 and another in 2007, and each case involved imported koi (McCleary et al. 2011). As of today, most western European countries, including Austria, Belgium, Denmark, France, Italy, Luxemburg, Romania, Slovenia, Spain, Sweden, Switzerland, and the Netherlands have reported positive tests for CyHV-3 (Pokorova et al. 2005, OIE 2012).

\section{Asia}

An international taskforce was established in an attempt to determine the cause of a 2002 disease outbreak in Indonesia. Subsequently, a unique Indonesian isolate of CyHV-3 (a hybrid of the US/I and Japan isolate) was isolated and identified from regions of Indonesia (Bondad-Reantaso et al. 2007, Sunarto et al. 2011). KHVD was first detected in Japan in 2003 during a mass mortality event of farmed carp in Lake Kasumigaura, Ibaragi prefecture (Sano et al. 2004). Thereafter, CyHV-3 was detected by PCR- and ELISA-based assays in wild carp in Lake Biwa, and CyHV-3-DNA was detected in water samples from 4 sites along the Tamagawa River in Tokyo, Japan, during 2006; since then, CyHV-3 has been confirmed in $90 \%$ of the 109 national class-A natural rivers in Japan (Ishioka et al. 2005, Sano et al. 2005, Haramoto et al. 2009, Uchii et al. 2009, Minamoto et al. 2012). Mortality due to CyHV-3 was detected in northern Taiwan in 2002 (Tu et al. 2004), and mass mortality events were first observed in 2003 in southern Taiwan fisheries (Cheng et al. 2011). CyHV-3 has been detected in China (Dong et al. 2011) and in koi broodstock in South Korea (Gomez et al. 2011, Lee et al. 2012, Han et al. 2013).

\section{North America}

Since the initial detection of KHVD in the US, conventional and real-time PCR with pooled samples from liver, spleen, and kidney taken from carp during a 2004 mass mortality event of wild common carp in 
New York confirmed that the fish were infected by CyHV-3 (Grimmett et al. 2006). Subsequently, CyHV-3 was detected in Ontario, Canada, in 2007, and thereafter, multiple lakes in Ontario suffered gross carp mortality events due to KHVD (Garver et al. 2010). According to the Michigan Department of Natural Resources, there have been recent carp mass mortalities caused by CyHV-3 in the northern Midwest region of the US bordering Canada (Whalen 2011). It seems that the virus is spreading westward along the US/Canada border.

\section{DETECTION}

CyHV-3 was originally differentiated from channel catfish virus and cyprinid herpesviruses by polypeptide analysis that revealed novel peptides in purified viral extracts and by restriction analysis of purified DNA extracts. The latter technique led to the preliminary PCR-based method of detection (Gilad et al. 2002). Subsequently, a PCR-based method was developed based on the amplification of the TK gene (Bercovier et al. 2005). Loop-mediated isothermal amplification (LAMP) of the TK gene allows for detection of CyHV-3 in a 1-step process without requiring a thermal cycler (Gunimaladevi et al. 2004, Yoshino et al. 2006, 2009). Detection of CyHV-3 can be accomplished by nested PCR or by capturing viral particles with antibodies followed by LAMP to detect viral particles (El-Matbouli et al. 2007a, Soliman \& ElMatbouli 2009). Real-time PCR, nested PCR, and semi-nested PCR are among the most sensitive tools

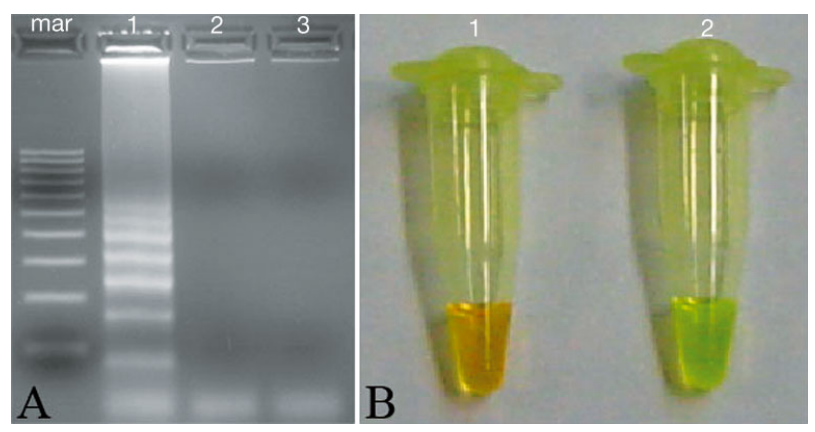

Fig. 2. Detection methods for koi herpesvirus (KHV). (A) Agarose gel showing LAMP products of KHV DNA extracted by boiling. The reaction was carried out at $65^{\circ} \mathrm{C}$ using the 6 primers. Lanes: $\mathrm{mar}=100 \mathrm{bp}$ molecular weight marker, $1=$ KHV DNA extracted by boiling, $2=$ negative fish tissue, 3 = negative control. (B) Visual detection of KHV LAMP products using SYBR Green I stain. 1: Negative LAMP reaction remained orange; 2 : positive LAMP reaction turned green. (Image from Soliman \& El-Matbouli 2005) for detection of CyHV-3 (Bergmann et al. 2010b). In one of the more elegant detection methods for CyHV3 by Soliman \& El-Matbouli (2005), the product of LAMP-PCR is visualized by mixing with SYBR-Green I to confirm positive results for CyHV-3 (Fig. 2). Differentiation of the CyHV-3 isolates from Israel, Japan, and the US can be accomplished by analysis of a variable number of tandem repeats in coding and noncoding regions (Avarre et al. 2011). In addition to the various molecular methods to detect CyHV-3, a monoclonal antibody produced against ORF68 has also been developed to be used for confirming CyHV-3 by immunohistochemistry (Akoi et al. 2011). A sensitive enzyme-linked immunosorbent assay (ELISA) that probes for captured carp anti-KHV antibodies was developed for the indirect detection of CyHV-3 by Adkison et al. (2005); another one by St-Hilaire et al. (2009). A further ELISA that uses anti-KHV antibody to probe for captured KHV particles was developed by Dishon et al. (2005) and is sold as a commercial kit. Fish suffering from KHVD are known to have secondary bacterial infections (Haenen et al. 2004), so a PCRbased method was coupled with DNA-array technology to rapidly detect $\mathrm{CyHV}-3$ positive fish that are infected with Flavobacterium (Lievens et al. 2011) or other bacteria. A primer probe designed against an exonic mRNA coding sequence allows for the detection of CyHV-3 during the replication stage (Yuasa et al. 2012).

\section{MODE OF ENTRY}

Bioluminescent assays using a luciferase-expressing recombinant CyHV-3 genome cloned into a bacterial artificial chromosome (BAC) revealed that CyHV-3 may enter through the skin in conjunction with the previously presumed route of entry, the gill (Costes et al. 2009). Epidermal abrasions provide sites susceptible to viral entry, and wound healing regions are also susceptible to viral entry (Raj et al. 2011). Feeding on CyHV-3-positive material provides an additional mode of entry for CyHV-3 through the pharyngeal periodontal mucosa during mastication, and it is known that CyHV-3 replicates profusely in the intestine (Fournier et al. 2012) rather than entering through the intestine (Ilouze et al. 2010). Inflammatory response and TK mRNAs are detectable in carp intestine $3 \mathrm{~d}$ post immersion with CyHV-3, and claudin genes (claudin-2, -3, -11, and -23) that participate in the maintenance of tight junctions in epithelial cells are modulated in the gut during CyHV-3 infection (Syakuri et al. 2013). 


\section{TRANSMISSION}

\section{Environmental factors}

CyHV-3 induces high mortality for koi at temperatures between 18 and $28^{\circ} \mathrm{C}$, but no mortality was observed for CyHV-3-exposed fish at $13^{\circ} \mathrm{C}$ (Gilad et al. 2003). CyHV-3 is transmitted horizontally via the excrement of diseased fish; therefore, having high densities of fish such as in aquaculture enterprises will exacerbate a CyHV-3 outbreak by facilitating the release of high levels of CyHV-3 via the excrement of diseased fish (Dishon et al. 2005). CyHV-3 titers in water of contaminated rivers and lakes can be measured by concentrating viral particles using ultracentrifugation or cationic-coated filters followed by quantitative real-time PCR (qPCR) (Honjo et al. 2010). Use of qPCR has demonstrated that CyHV-3 concentrations vary in nearby plankton deposit sites and are likely concentrated by filter-feeding Rotifera (Minamoto et al. 2011). CyHV-3 may be transmitted to carp when feeding on plankton directly, or on bivalves that have fed on plankton and have concentrated $\mathrm{CyHV}-3$ in their digestive tubes (Minamoto et al. 2011). Other filter-feeding organisms, such as freshwater mollusks and crustaceans, can also test positive for CyHV-3 (Kielpinski et al. 2010). Mating may also increase the prevalence of CyHV-3 by aggregating infected fish and/or causing a reduction of the immune response (Uchii et al. 2011). Significant levels of CyHV-3 DNA were detected in a lagoon 1 mo before a mass mortality event, and similar concentrations were also detected in a lake that had been free of CyHV-3-associated mass mortality events for $3 \mathrm{yr}$ (Honjo et al. 2010). Some strains of bacteria naturally clear water of $\mathrm{CyHV}-3$ and thereby reduce the infectivity of $\mathrm{CyHV}-3$ in natural environments within a few days (Shimizu et al. 2006).

\section{Carriers}

Survivors of KHVD have CyHV-3 DNA in liver, heart, gill, and eye, and CyHV-3 may persist in cells of the gastrointestinal epithelium or in leukocytes (Bergmann et al. 2009, Eide et al. 2011a). Surviving carp are carriers of CyHV-3 and can excrete virus especially following stress-related activities such as nesting (Bergmann \& Kempter 2011). Goldfish have been shown to host CyHV-3 virus when co-habitated with infected koi (ElMatbouli et al. 2007b, Bergmann et al. 2010a).
Goldfish have also been reported to act as carriers for CyHV-3 in the US (Sadler et al. 2008). Leukocytes from both koi and goldfish have tested positive for CyHV-3. In addition, in cohabitation studies, the infected goldfish transmitted virus to naïve koi as demonstrated by immunostaining with antiCyHV-3 serum, in situ hybridization, and PCR (Bergmann et al. 2010a). In a similar study, goldfish were shown to act as a carrier for CyHV-3 in cohabitation experiments with naïve common carp (El-Matbouli \& Soliman 2011). Nested PCR has revealed CyHV-3 DNA in samples of healthy fish including grass carp Ctenopharyngodon idella, blue back ide Leuciscus idus, and Ancistrus sp., suggesting that these fish species may be potential carriers of CyHV-3 (Bergmann et al. 2009). Similarly, Russian sturgeons Acipenser gueldenstaedtii and Atlantic sturgeons A. oxyrinchus have also tested positive for CyHV-3 DNA by PCR-based methods (Kempter et al. 2009).

\section{Factors affecting infection}

Although young and adult common carp are susceptible to CyHV-3, carp larvae are impervious to infection by CyHV-3 (Ito et al. 2007). Single nucleotide polymorphisms in the innate immune response genes of carp, such as in Toll-like or in the IL-10a gene, may differentiate resistance to CyHV-3 (Kongchum et al. 2010, 2011). Upregulation of 8 immune-related genes, including interferon inducible protein gig-1 like and suppressor of cytokine signaling 1 were observed in survivors of KHVD, in addition to a more rapid cytokine reaction to KHV (Rakus et al. 2012). CyHV-3 may also be able to modulate the interferon response in different cell types (Adamek et al. 2012). CyHV-3 infection downregulates skin defense genes such as muc5B, a component of the mucus blanket, claudins $(23,30)$, which are important for maintenance of tight junctions, and antimicrobial peptides such as $\beta$-defensin-1 and -2, involved in secondary bacterial infections (Adamek et al. 2013). However, mucus provides an innate protection against viral entry by providing fish with a viscous barrier against entry and as a storage medium for viral neutralizing factors (Raj et al. 2011). Therefore, although the skin may be susceptible to CyHV-3 entry (Costes et al. 2009), due to the protection that mucus provides, the digestive tract and or gill tissues are the more likely paths for CyHV-3 entry (S. M. Bergmann pers. obs.). 


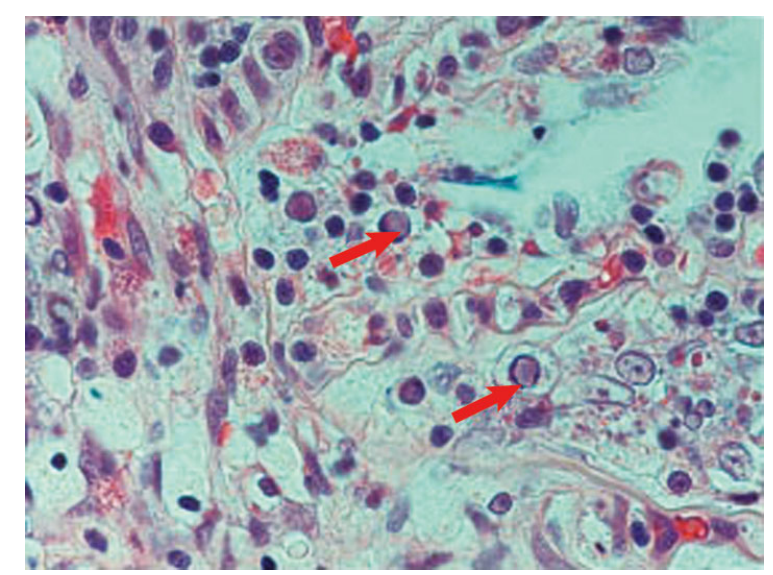

Fig. 3. Cyprinus carpio. Koi herpesvirus forming inclusion bodies (arrows) in gill epithelium of common carp

\section{HISTOPATHOLOGICAL EFFECT OF CYHV-3}

Characteristics of CyHV-3-infected fish include loss of appetite, erratic and uncoordinated movement, and gasping for air (Hutoran et al. 2005). CyHV-3 was detected in the mucus as early as $1 \mathrm{~d}$ post infection, and significant titers were also detectable in the brain, spleen, kidney, liver, and gut of infected koi (Gilad et al. 2004). The main clinical signs of CyHV-3 disease include: loss of epidermis, discoloration, erosion of fin extremities, and an increase in mucus production in gills (Bretzinger et al. 1999). Histopathological changes induced by CyHV-3 include: lesions and necrosis in gill and interstitial kidney tissues, and focal necrosis in the liver and nuclear inclusion bodies in gill tissue (Fig. 3) and in renal glomerulae
(Perelberg et al. 2003). CyHV-3 infected common carp displayed inclusion bodies in splenocytes, nuclear degeneration in the myocardial cells, and congestion of capillaries in small veins of the brain (Miyazaki et al. 2008). Additionally, CyHV-3 causes hyperplasia of the epithelium lining of the gastric gland in the stomach and of the intestinal villi in the intestine forming cystic papillary projections, and hyperplasia of respiratory cells resulting in the fusion of lamella and hemorrhaging at the tips of lamella in the gills (El-Din 2011).

\section{CELL CULTURE AND VIRAL REPLICATION}

CyHV-3-infected cells display a dense cytoplasm with organelle morphology that degrades as viral replication progresses (Miyazaki et al. 2008). CyHV-3 has been cultured in koi caudal fin (KF-1) and common carp brain (CCB) (Fig. 4) cell cultures, and has been shown to replicate in cell cultures derived from silver carp Hypophthalmichthys molitrix and goldfish (Neukirch \& Kunz 2001, Davidovich et al. 2007, Bergmann et al. 2010a, Dong et al. 2011). CPE caused by infection with CyHV-3 has also been observed $15 \mathrm{~d}$ post inoculation of FHM (Grimmett et al. 2006). Optimal replication for $\mathrm{CyHV}-3$ in the KF-1 cell-line occurs between 15 and $25^{\circ} \mathrm{C}$ (Gilad et al. 2003). Realtime PCR determined that a minimum of $6 \times 10^{3}$ genomic equivalents of $\mathrm{CyHV}-3$ are needed to observe $\mathrm{CPE}$ in $10^{6} \mathrm{KF}-1$ (koi fin) cells, and CyHV-3 titers range between $10^{7}$ and $10^{9}$ genomic equivalents per $10^{6} \mathrm{KF}-1$ cells during peak infection in mucus, liver, kidney, spleen, gut, and brain (Gilad et al. 2004).

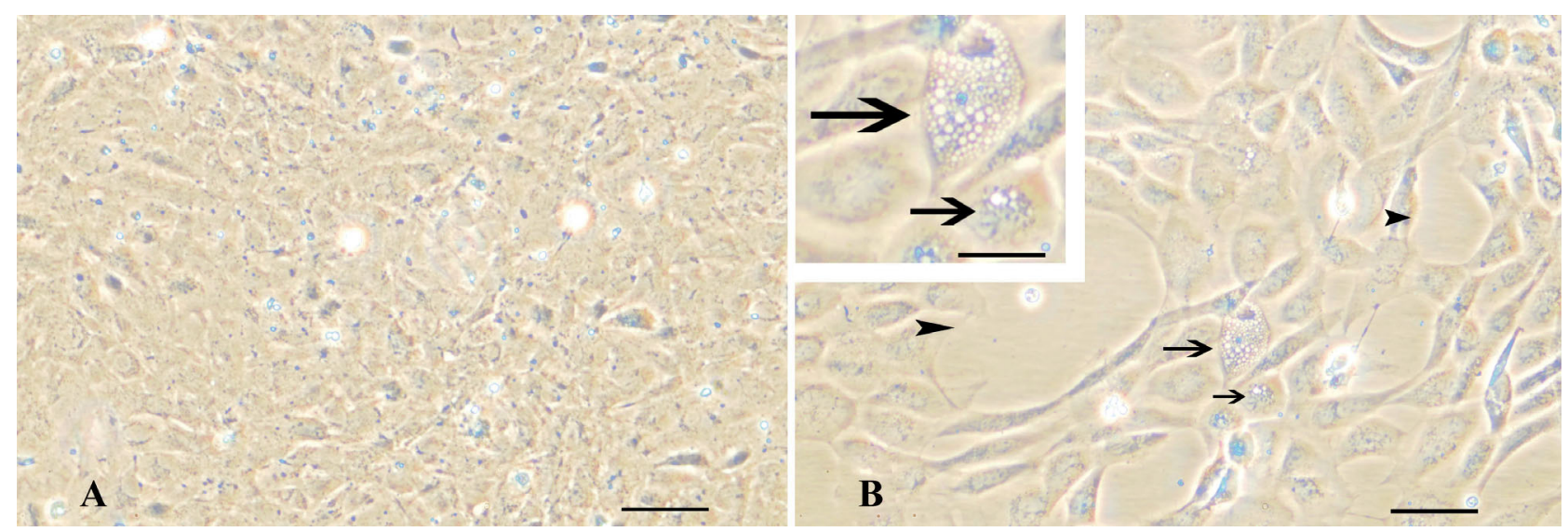

Fig. 4. Cyprinus carpio. Koi herpesvirus (KHV) in common carp brain cell culture. Images were taken $13 \mathrm{~d}$ after passaging. (A) Non-infected cells. (B) Cells $11 \mathrm{~d}$ post KHV infection. Arrows point to CyHV-3-infected cells and arrow heads point to CyHV-3-induced cell clearance. Cytoplasmic vacuolation is visible for both infected cells in the inset, and the lower cell shows signs of syncytia formation. Scale bar $=(A, B) 50 \mu \mathrm{m}$, (Inset) $100 \mu \mathrm{m}$ 


\section{MORPHOGENESIS}

Electron microscope images of maturing virus showed that CyHV-3 replicates in the nucleus and forms capsids with characteristics similar to those of mammalian herpesviruses in terms of protrusions into and through the nuclear membrane (Miwa et al. 2007). Initially in the nucleus, immature CyHV-3 nucleocapsids that have low electron density and are $100 \mathrm{~nm}$ in diameter are formed. Subsequently, mature nucleocapsids with high electron density and $117 \mathrm{~nm}$ in diameter are formed (Miyazaki et al. 2008). Mature capsids with a diameter between 150 and $180 \mathrm{~nm}$ are located in the perinuclear region where they begin to bud off and take with them part of the nuclear envelope (Miyazaki et al. 2008). Transmission electron microscopic studies (TEM) of CyHV-3 show that the virus forms a symmetrical icosahedron; however, the viral core region is an asymmetrical electron-dense region where the genomic DNA and nucleoprotein complex exist (Hutoran et al. 2005). The electron-dense core of mature CyHV-3, as observed with TEM, shows the diameter to be between 170 and $230 \mathrm{~nm}$ and the protein core to be $110 \mathrm{~nm}$ (Cheng et al. 2011).

\section{FUNCTIONAL GENES}

The genome of each of the CyHV-3 isolates (Israel, Japan, and USA) consists of $295 \mathrm{kB}$ with a $22 \mathrm{kB}$ terminal repeat; therefore, the 164 potential ORFs consist of 8 repeated ORFs that flank both ends of the genome (Aoki et al. 2007). Of the 156 unique potential ORFs in the CyHV-3 genome, mass spectrometry studies identified 40 proteins in mature virions that include 3 capsid proteins, 13 envelope proteins, 2 tegument proteins, and 22 structural proteins that are yet to be classified (Michel et al. 2010b). A recent report by Ilouze et al. (2012a) demonstrated by reverse transcriptase-real-time PCR that all 156 ORFs of CyHV-3 are transcribed, and the ORFs have been annotated in terms of relative transcriptional timing. Three genes involved in the synthesis of dNTPs required for DNA synthesis, viz. thymidylate monophosphate kinase, ribonucleotide reductase (RNR), and TK, share homology with pox virus genes (Ilouze et al. 2006). However, TK, RNR, and another gene involved in DNA synthesis, deoxyuridine triphosphate pyrophosphatase, are non-essential for viral replication in CCB cell lines, but these genes are important virulence factors in affecting clinical signs and mortality (Fuchs et al. 2011). The protein encoded by ORF81 was shown to be incorporated into the viral envelope of intact CyHV-3 particles by immunogold microscopy (Rosenkranz et al. 2008). A majority of CyHV-3 genes involved in DNA synthesis are eliminated within $24 \mathrm{~h}$ in infected CCB cells that are transferred to $30^{\circ} \mathrm{C}$ (i.e. non-permissive temperatures); however, TK, B22Rh, ITP (intercapsomeric triplex protein), and clone Y genes persist for up $15 \mathrm{~d}$ after transfer (Dishon et al. 2007). In a parallel experiment in the aforementioned report, B22R homolog, Orf4, Orf5, and Gray Sph1hpi were the first 4 genes to be re-transcribed after infected cells were incubated for $22 \mathrm{~d}$ at $30^{\circ} \mathrm{C}$ to clear CyHV-3 transcripts and re-transferred to $22^{\circ} \mathrm{C}$ (i.e. permissive temperature). A BAC carrying the entire CyHV-3 genome with disruption to the TK gene displayed reduced virulence and caused $50 \%$ reduction in mortality in koi compared to a revertant BAC that had an additional gene producing TK (Costes et al. 2008). Protein screening with an antibody against glycoprotein ORF56 revealed that CyHV-3 interacts with a number of host defense proteins that include lysozymes and granulins, and with machinery involved in protein modification such as protease inhibitor, glutathione S-transferase rho, and members of the ubiquitin degradation pathway (Gotesman et al. 2013). ORF134 encodes a homolog of interleukin-10, expression of which is higher during acute and activation phases of CyHV-3 disease (Sunarto et al. 2012).

\section{PROPHYLAXIS AND CONTROL}

\section{Immunization}

Immunization against CyHV-3 is achieved by exposing carp for 2 to $3 \mathrm{~d}$ with infectious CyHV-3 and subsequently transferring the exposed carp to a nonpermissive temperature $\left(30^{\circ} \mathrm{C}\right)$, or by using a live attenuated virus produced by in vitro serial passages and treatment with ultraviolet (UV) irradiation (Ronen et al. 2003, Perelberg et al. 2005). Challenge with an attenuated or wild-type virus demonstrated that antibodies produced in the infected fish can neutralize CyHV-3 in vivo (Perelberg et al. 2008). Adkison et al. (2005) also demonstrated that treatment with a CyHV-3-induced antibody can attenuate CyHV-3 infection. Surviving koi that were inoculated with a BAC-derived strain carrying either full strength or attenuated CyHV-3 were resistant to CyHV-3 disease (Costes et al. 2008). A US patent has been filed based on the aforementioned method of immunization (Costes et al. 2011). Mathematical 
modeling predicts that inoculation of farmed fish with CyHV-3 during autumn will produce KHVDresistant carp in readiness for the following permissive seasons (Omori \& Adams 2011).

\section{Immunized carp become carriers?}

A potential flaw in immunizing carp against CyHV3 by temperature shift is that immunized fish can become carriers for the virus. This threat was demonstrated by the re-emergence of CyHV-3 in cultures of the CCB cell line that were acutely exposed to CyHV-3 and later moved to a non-permissive temperature $\left(30^{\circ} \mathrm{C}\right)$ for $30 \mathrm{~d}$ (Dishon et al. 2007). Furthermore, Bretzinger et al. (1999) initially reported that CyHV-3-affected koi maintained at $12^{\circ} \mathrm{C}$ (i.e. nonpermissive temperature) were sub-clinical; however, they soon showed clinical signs and died when the temperature was raised to $21^{\circ} \mathrm{C}$ (i.e. permissive temperature). Sub-clinical fish that were immunized for CyHV-3 by incubation at $12^{\circ} \mathrm{C}$ (i.e. non-permissive temperature) suffered a $57 \%$ mortality rate, and naïve (non-infected) fish suffered a 100\% mortality rate when they were cohabitated at $20^{\circ} \mathrm{C}$ (St-Hilaire et al. 2005). Furthermore, CyHV-3-infected fish carried detectable antibody specific for $\mathrm{CyHV}-3$ for up to 65 wk post exposure, and developed CyHV-3 disease signs and mortality even when incubated at a non-permissive temperature $\left(12^{\circ} \mathrm{C}\right)$ for $25 \mathrm{wk}$ upon return to the permissive temperature (St-Hilaire et al. 2009). CyHV-3 remains latent in white blood cells and can be detected by real-time PCR in gill tissue and fecal deposits following heat stress (Bergmann et al. 2010b, Eide et al. 2011b). Cumulatively, the aforementioned reports suggest high potential for CyHV3 to persist in sub-clinical carriers and infect naïve fish, and immunization will further propagate the virus.

\section{Crossbreeding}

Domestic Israeli carp strains, known as Dor-70 and Našice (from the former Yugoslavia), that were crossbred with a native Czech strain known as Sasson showed significant higher survival rates to KHVD (64 and $69 \%$ ) compared with those of the parental strains Dor-70 and Našice (28 and 9\%, respectively; Shapira et al. 2005). Similar experiments in the UK showed that crossbreeding carp with a 'wild' strain originating from the Amor or Duna Rivers in Hungary produced carp that were more resistant to
KHVD than domesticated carp (Dixon et al. 2009). Crossbreeds of koi $\times$ crucian carp Carassius carassius and koi $\times$ goldfish were analyzed for resistance to KHVD. Both crossbreeds showed pathological signs of KHVD; however, although the common koi $\times$ crucian carp hybrid showed similar mortality levels to a pure carp breed following CyHV-3-I infection (91 and $100 \%$, respectively), hybrids between koi and goldfish showed reduced mortality (35\%; Bergmann et al. 2010c).

\section{CONCLUSION}

CyHV-3 was initially described by Hedrick et al. (2000) as a serious virus affecting koi and common carp in the US and Israel. Currently, CyHV-3 is a serious epidemic threat to koi and common carp worldwide in terms of koi breeding, and for common carp production in natural environments and in aquaculture. CyHV-3 is a member of the family Alloherpesviridae, and is a double-stranded DNA virus that consists of a $295 \mathrm{~kb}$ genome which codes for 156 genes, all of which have been annotated and demonstrated to be transcribed (Ilouze et al. 2012a). The virus can replicate in a number of cell lines including CCB, KF-1, and EPC. KHVD is limited to koi and common carp; however, goldfish, blue back ide, and Russian and Atlantic sturgeons may act as carriers for the virus. Specific and validated diagnostic methods for detection and identification, especially for subclinical infections, were predicted to be the most important tool to contain the spread of CyHV-3 (Pearson 2004); however, the virus has spread in Europe, Asia, and North America.

A practical use for CyHV-3 has been described in Australia, where carp have been introduced and are considered a pest species that has recently been linked to the decline of native Australian fish species. CyHV-3 is considered as a potential control agent for eradicating carp in Australia (McColl et al. 2007). Fortunately, CyHV-3 has not been detected in India by using either the PCR primers developed by Ronen et al. (2003) or newly developed primers that specifically target the major capsid protein of CyHV-3 (Rathore et al. 2009). However, other major carpproducing countries, such as China, Indonesia, and Japan, have seen elevated incidence of KHVD (Dong et al. 2011, Avarre et al. 2012, Minamoto et al. 2012).

Several steps have been taken in recent years to control the spread of CyHV-3, such as recognition of the threat and development of rapid and sensitive tools for detection of the virus. Other methods 
include immunization of carp by infection with 'wildtype' infectious virus and subsequently transferring the fish to temperatures that are non-permissive for CyHV-3 replication or by infection of carp with attenuated virus. Selective breeding programs to breed KHVD-resistant carp have also been initiated. Any effort to contain CyHV-3 must recognize that survivors of CyHV-3 outbreaks can become carriers for the virus (St-Hilaire et al. 2005, Uchii et al. 2009, Bergmann et al. 2010b, Eide et al. 2011b, Ilouze et al. 2012b).

Acknowledgements. This study was funded by the Austrian Science Fund (FWF), Project no. P23550-B13.

\section{LITERATURE CITED}

Adamek M, Rakus KL, Chyb J, Brogden G, Huebner A, Irnazarow I, Steinhagen D (2012) Interferon type I responses to virus infections in carp cells: in vitro studies on cyprinid herpesvirus 3 and Rhabdovirus carpio infections. Fish Shellfish Immunol 33:482-493

Adamek M, Syakuri H, Harris S, Rakus KL and others (2013) Cyprinid herpesvirus 3 infection disrupts the skin barrier of common carp (Cyprinus carpio L.). Vet Microbiol 162: $456-470$

Adkison M, Gilad O, Hedrick RP (2005) An enzyme linked immunosorbent assay (ELISA) for detection of antibodies to the koi herpesvirus (KHV) in the serum of koi Cyprinus carpio. Fish Pathol 40:53-62

Antychowicz J, Reichert M, Matras M, Bergmann SW, Haenan O (2005) Epidemiology, pathogenicity and molecular biology of koi herpesvirus isolated in Poland. Bull Vet Inst Pulawy 49:367-373

Aoki T, Hirono I, Kurokawa K, Fukuda H and others (2007) Genome sequences of three koi herpesvirus isolates representing the expanding distribution of an emerging disease threatening koi and common carp worldwide. J Virol 81:5058-5065

Aoki T, Takano T, Unajak S, Takagi M and others (2011) Generation of monoclonal antibodies specific for ORF68 of koi herpesvirus. Comp Immunol Microbiol Infect Dis 34:209-216

> Avarre JC, Madeira JP, Santika A, Zainun Z and others (2011) Investigation of cyprinid herpesvirus-3 genetic diversity by a multi-locus variable number of tandem repeats analysis. J Virol Methods 173:320-327

Avarre JC, Santika A, Bentenni A, Zainun Z and others (2012) Spatio-temporal analysis of cyprinid herpesvirus 3 genetic diversity at a local scale. J Fish Dis 35:767-774

Bercovier H, Fishman Y, Nahary R, Sinai S and others (2005) Cloning of the koi herpesvirus (KHV) gene encoding thymidine kinase and its use for a highly sensitive PCRbased diagnosis. BMC Microbiol 5:13-22

Bergmann SM, Kempter J (2011) Detection of koi herpesvirus (KHV) after re-activation in persistently infected common carp (Cyprinus carpio L.) using nonlethal sampling methods. Bull Eur Assoc Fish Pathol 31: 92-104

Bergmann SM, Kempter J, Sadowski J, Fichtner D (2006) First detection, confirmation and isolation of koi her- pesvirus (KHV) in cultured common carp (Cyprinus carpio L.) in Poland. Bull Eur Assoc Fish Pathol 26:97-104

Bergmann SM, Schütze H, Fischer U, Fichtner D and others (2009) Detection of koi herpes virus (KHV) genome in apparently healthy fish. Bull Eur Assoc Fish Pathol 29: 145-152

Bergmann SM, Lutze P, Schütze H, Fischer U, Dauber M, Fichtner D, Kempter J (2010a) Goldfish (Carassius auratus auratus) is a susceptible species for koi herpesvirus (KHV) but not for KHV disease (KHVD). Bull Eur Assoc Fish Pathol 30:74-83

Bergmann SM, Riechart M, Fichtner D, Leeb P, Kempter J (2010b) Investigation on the diagnostic sensitivity of molecular tools used for detection of koi herpesvirus. J Virol Methods 163:229-233

Bergmann SM, Sadowski J, Kielpinski M, Bartlomiejczyk M, Fichtner D, Riebe R (2010c) Susceptibility of koi $\times$ crucian carp and koi $\times$ goldfish hybrids to koi herpesvirus (KHV) and the development of KHV disease (KHVD). J Fish Dis 33:267-272

Bigarré L, Baud M, Cabon J, Antychowicz J and others (2009) Differentiation between cyprinid herpesvirus type-3 lineages using duplex PCR. J Virol Methods 158: 51-57

> Bondad-Reantaso MG, Sunarto A, Subasinghe RP (2007) Managing the koi herpesvirus disease outbreak in Indonesia and the lessons learned. Dev Biol 129:21-28

Bretzinger A, Fischer-Scherl T, Oumouna M, Hoffmann R, Truyen U (1999) Mass mortality in koi carp, Cyprinus carpio, associated with gill and skin disease. Bull Eur Assoc Fish Pathol 19:182-185

Calle PP, McNamara T, Kress Y (1999) Herpesvirus-associated papillomas in koi carp (Cyprinus carpio). J Zoo Wildl Med 30:165-169

Cheng L, Chen CY, Tsai MA, Wang PC, Hsu JP, Chern RS, Chen SC (2011) Koi herpesvirus epizootic in cultured carp and koi, Cyprinus carpio L., in Taiwan. J Fish Dis 34: 547-554

Costes B, Fournier G, Michel B, Delforge C and others (2008) Cloning of the koi herpesvirus genome as an infectious bacterial artificial chromosome demonstrates that disruption of the thymidine kinase locus induces partial attenuation in Cyprinus carpio koi. J Virol 82: 4955-4964

Costes B, Raj VS, Michel B, Fournier G and others (2009) The major portal of entry of koi herpesvirus in Cyprinus carpio is the skin. J Virol 83:2819-2830

Costes B, Vanderplasschen AFC, Lieffrig F (2011) Recombinant koi herpesvirus (KHV) or cyprinid herpesvirus 3 $(\mathrm{CyHV}-3)$ and a vaccine for the prevention of a disease caused by KHV/CyHV-3 in Cyprinus carpio carpio or Cyprinus carpio koi. Patent: US 2011/0287050 A1. www. google.com/patents/US20110287050

Davidovich M, Dishon A, Ilouze M, Kotler M (2007) Susceptibility of cyprinid cultured cells to cyprinid herpesvirus 3. Arch Virol 152:1541-1546

> Dishon A, Perelberg A, Bishara-Shieban J, Ilouze M, Davidovich M, Werker S, Kotler M (2005) Detection of carp interstitial nephritis and gill necrosis virus in fish droppings. Appl Environ Microbiol 71:7285-7291

> Dishon A, Davidovich M, Ilouze M, Kotler M (2007) Persistence of cyprinid herpesvirus 3 in infected cultured carp cells. J Virol 81:4828-4836

Dixon PF, Joiner CL, Way K, Reese RA, Jeney G, Jeney Z (2009) Comparison of the resistance of selected families 
of common carp, Cyprinus carpio L., to koi herpesvirus: preliminary study. J Fish Dis 32:1035-1039

> Dong C, Weng S, Li W, Li X, Yi Y, Liang Q, He J (2011) Characterization of a new cell line from caudal fin of koi, Cyprinus carpio koi, and first isolation of cyprinid herpesvirus 3 in China. Virus Res 161:140-149

Eide K, Miller-Morgan T, Heidel JR, Bildfell RJ, Jin L (2011a) Results of total DNA measurement in koi tissue by Koi Herpesvirus real-time PCR. J Virol Methods 172: 81-84

Eide KE, Miller-Morgan T, Heidel JR, Kent ML and others (2011b) Investigation of Koi Herpesvirus latency in koi. J Virol 85:4954-4962

El-Din MMM (2011) Histopathological studies in experimentally infected koi carp (Cyprinus carpio koi) with koi herpesvirus in Japan. World J Fish Mar Sci 3:252-259

El-Matbouli M, Soliman H (2011) Transmission of cyprinid herpesvirus-3 (CyHV-3) from goldfish to naïve common carp by cohabitation. Res Vet Sci 90:536-539

El-Matbouli M, Rucker U, Soliman H (2007a) Detection of Cyprinid herpesvirus-3 (CyHV-3) DNA in infected fish tissues by nested polymerase chain reaction. Dis Aquat Org 78:23-28

El-Matbouli M, Saleh M, Soliman H (2007b) Detection of cyprinid herpesvirus type 3 in goldfish cohabiting with CyHV-3-infected koi carp (Cyprinus carpio koi). Vet Rec 161:792-793

FAO (Food and Agriculture Organization of the United Nations) (2010) The state of world fisheries and aquaculture 2010. FAO, Rome

- Fournier G, Boutier M, Raj VS, Mast J and others (2012) Feeding Cyprinus carpio with infectious materials mediates cyprinid herpesvirus 3 entry through infection of pharyngeal periodontal mucosa. Vet Res 43:6

Fuchs W, Fichtner D, Bergmann SM, Mettenleiter TC (2011) Generation and characterization of koi herpesvirus recombinants lacking viral enzymes of nucleotide metabolism. Arch Virol 156:1059-1063

Garver KA, Al-Hussinee L, Hawley LM, Schroeder T and others (2010) Mass mortality associated with koi herpesvirus in wild common carp in Canada. J Wildl Dis 46: 1242-1251

Gilad O, Yun S, Andree KB, Adkison MA and others (2002) Initial characteristics of koi herpesvirus and development of a polymerase chain reaction assay to detect the virus in koi, Cyprinus carpio koi. Dis Aquat Org 48: 101-108

> Gilad O, Yun S, Adkison MA, Way K, Willits NH, Bercovier H, Hedrick RP (2003) Molecular comparison of isolates of an emerging fish pathogen, the koi herpesvirus, and the effect of water temperature on mortality of experimentally infected koi. J Gen Virol 84: 2661-2667

Gilad O, Yun S, Zagmutt-Vergara FJ, Leutenegger CM, Bercovier H, Hedrick RP (2004) Concentrations of a koi herpesvirus (KHV) in tissues of experimentally-infected Cyprinus carpio koi as assessed by real-time TaqMan PCR. Dis Aquat Org 60:179-187

Gomez DK, Joh SJ, Jang H, Shin SP and others (2011) Detection of koi herpesvirus (KHV) from koi (Cyprinus carpio koi) broodstock in South Korea. Aquaculture 311:42-47

Goodwin AE, Khoo L, LaPatra SE, Bonar C and others (2006a) Goldfish hematopoietic necrosis herpesvirus (cyprinid herpesvirus 2) in the USA: molecular confirma- tion of isolates from diseased fish. J Aquat Anim Health 18:11-18

Goodwin AE, Merry GE, Sadler J (2006b) Detection of the herpesviral hematopoietic necrosis disease agent (Cyprinid herpesvirus 2) in moribund and healthy goldfish: validation of a quantitative PCR diagnostic method. Dis Aquat Org 69:137-143

Goodwin AE, Sadler J, Merry GE, Marecaux EN (2009) Herpesviral haematopoietic necrosis virus (CyHV-2) infection: case studies from commercial goldfish farms. J Fish Dis 32:271-278

Gotesman M, Soliman H, El-Matbouli M (2013) Antibody screening identifies 78 putative host proteins involved in cyprinid herpesvirus 3 infection or propagation in common carp, Cyprinus carpio L. J Fish Dis 36:721-733

- Grimmett SG, Warg JV, Getchell RG, Johnson DJ, Bowser PR (2006) An unusual koi herpesvirus associated with a mortality event of common carp Cyprinus carpio in New York State, USA. J Wildl Dis 42:658-662

Groff JM, LaPatra SE, Munn RJ, Zinkl JG (1998) A viral epizootic in cultured populations of juvenile goldfish due to a putative herpesvirus etiology. J Vet Diagn Invest 10: 375-378

Gunimaladevi I, Kono T, Venugopal MN, Sakai M (2004) Detection of koi herpesvirus in common carp, Cyprinus carpio L., by loop-mediated isothermal amplification. J Fish Dis 27:583-589

Haenen OLM, Way K, Bergmann SM, Ariel E (2004) The emergence of koi herpesvirus and its significance to European aquaculture. Bull Eur Assoc Fish Pathol 24: 293-307

Han JE, Kim JH, Renault T, Shin SP, Jun JW, Park SC (2013) Identifying the viral genes encoding envelope glycoproteins for differentiation of cyprinid herpesvirus 3 isolates. Viruses 5:568-576

Haramoto E, Kitajima M, Katayama H, Ito T, Ohgaki S (2009) Development of virus concentration methods for detection of koi herpesvirus in water. J Fish Dis 32:297-300

Hedrick RP, Groff JM, Okihiro MS, McDowell TS (1990) Herpesviruses detected in papillomatous skin growths of koi carp (Cyprinus carpio). J Wildl Dis 26:578-581

> Hedrick RP, Gilad O, Yun SC, Spangenberg JV and others (2000) A herpesvirus associated with mass mortality of juvenile and adult koi, a strain of a common carp. J Aquat Anim Health 12:44-57

Hedrick RP, Gilad O, Yun SC, Mcdowell TS, Waltzek TB, Kelley GO, Adkison MA (2005) Initial isolation and characterization of a herpes-like virus (KHV) from koi and common carp. Bull Fish Res Agency Suppl 2:1-7

Honjo MN, Minamoto T, Matsui K, Uchii K and others (2010) Quantification of cyprinid herpesvirus 3 in environmental water by using an external standard virus. Appl Environ Microbiol 76:161-168

Hutoran M, Ronen A, Perelberg A, Ilouze M and others (2005) Description of an as yet unclassified DNA virus from diseased Cyprinus carpio species. J Virol 79: 1983-1991

> Ilouze M, Dishon A, Kahan T, Kotler M (2006) Cyprinid herpes virus-3 (CyHV-3) bears genes of genetically distant large DNA viruses. FEBS Lett 580:4473-4478

Ilouze M, Dishon A, Davidovich M, Perelberg A, Kotler M (2008) KHV, CNGV or CyHV-3, which is the koi/carp killer? Dis Asian Aquacult 6:115-128

Ilouze M, Davidovich M, Diamant A, Kotler M, Dishon A (2010) The outbreak of carp disease caused by CyHV-3 
as a model for new emerging viral diseases in aquaculture: a review. Ecol Res 26:885-892

> Ilouze M, Dishon A, Kotler M (2012a) Coordinated and sequential transcription of the cyprinid herpesvirus-3 annotated genes. Virus Res 169:98-106

Ilouze M, Dishon A, Kotler M (2012b) Down-regulation of the cyprinid herpesvirus-3 annotated genes in cultured cells maintained at restrictive high temperature. Virus Res 169:289-295

Ishioka T, Yoshizumi M, Izumi S, Suzuki K and others (2005) Detection and sequence analysis of DNA polymerase and major envelope protein genes in koi herpesviruses derived from Cyprinus carpio in Gunma prefecture, Japan. Vet Microbiol 110:27-33

> Ito T, Sano M, Kurita J, Yuasa K, Iida T (2007) Carp larvae are not susceptible to koi herpesvirus. Fish Pathol 42:107-109

> Jeffery KR, Bateman K, Bayley A, Feist SW and others (2007) Isolation of a cyprinid herpesvirus 2 from goldfish, Carassius auratus (L.), in the UK. J Fish Dis 30:649-656

> Jung SJ, Miyazaki T (1995) Herpesviral haematopoietic necrosis of goldfish, Carassius auratus (L.). J Fish Dis 18: 211-220

- Kempter J, Sadowski J, Schütze H, Fischer U and others (2009) Koi herpes virus: Do acipenserid restitution programs pose a threat to carp farms in the disease-free zones? Acta Ichthyol Piscat 39:119-126

Kielpinski M, Kempter J, Panicz R, Sadowski J, Schütze H, Ohlemeyer S, Bergmann SM (2010) Detection of KHV in freshwater mussels and crustaceans from ponds with KHV history in common carp (Cyprinus carpio). Isr J Aquacult 62:28-37

> Kongchum P, Palti Y, Lutzky S, Hallerman EM, Hulata G, David L (2010) SNP discovery and development of genetic markers for mapping innate immune response genes in common carp (Cyprinus carpio). Fish Shellfish Immunol 29:356-361

Kongchum P, Sandel E, Lutzky S, Hallerman EM, Hulata G, David L, Palti Y (2011) Association between $I L-10$ a single nucleotide polymorphism and resistance to cyprinid herpesvirus-3 infection in common carp (Cyprinus carpio). J Aquacult 315:417-421

Kurita J, Yuasa K, Ito T, Sano M and others (2009) Molecular epidemiology of koi herpesvirus. Fish Pathol 44:59-66

Lee NS, Jung SH, Park JW, Do JW (2012) In situ hybridization detection of koi herpesvirus in paraffin-embedded tissues of common carp Cyprinus carpio collected in 1998 in Korea. Fish Pathol 47:100-103

Lievens B, Frans I, Heusdens C, Justé A, Jonstrup SP, Lieffrig F, Willems KA (2011) Rapid detection and identification of viral and bacterial fish pathogens using a DNA array-based multiplex assay. J Fish Dis 34:861-875

McCleary S, Ruane NM, Cheslett D, Hickey C, Rodger HD, Geoghegan F, Henshilwood K (2011) Detection of koi herpesvirus (KHV) in koi carp (Cyprinus carpio L.) imported into Ireland. Bull Eur Assoc Fish Pathol 31:124-128

McColl K, Sunarto A, Williams LM, Crane MSTJ (2007) The koi herpesvirus: dreaded pathogen or white knight? Aquacult Health Int 9:4-6

Michel B, Fournier G, Lieffrig F, Costes B, Vanderplasschen A (2010a) Cyprinid herpesvirus 3. Emerg Infect Dis 16, doi:10.3201/eid1612.100593

Michel B, Leroy B, Stalin Raj V, Lieffrig F and others (2010b) The genome of cyprinid herpesvirus 3 encodes 40 proteins incorporated in mature virions. J Gen Virol 91: $452-462$
Minamoto T, Honjo MN, Yamanaka H, Tanaka N, Itayama T, Kawabata Z (2011) Detection of cyprinid herpesvirus3 DNA in lake plankton. Res Vet Sci 90:530-532

Minamoto T, Honjo MN, Yamanaka H, Uchii K, Kawabata Z (2012) Nationwide Cyprinid herpesvirus 3 contamination in natural rivers of Japan. Res Vet Sci 93:508-514

Miwa S, Ito T, Sano M (2007) Morphogenesis of koi herpesvirus observed by electron microscopy. J Fish Dis 30: $715-722$

> Miyazaki T, Kuzuya Y, Yasumoto S, Yasuda M, Kobayashi T (2008) Histopathological and ultrastructural features of Koi herpesvirus (KHV)-infected carp Cyprinus carpio, and the morphology and morphogenesis of KHV. Dis Aquat Org 80:1-11

Neukirch M, Kunz U (2001) Isolation and preliminary characterization of several viruses from koi (Cyprinus carpio) suffering gill necrosis and mortality. Bull Eur Assoc Fish Pathol 21:125-134

OIE (World Organisation for Animal Health) (2012) Manual of diagnostic tests for aquatic animals, 7th edn. OIE, Paris. Available at www.oie.int/fileadmin/Home/eng/Health_ standards/aahm/2010/2.3.06_KHVD.pdf (accessed $2 \overline{5}$ April 2013)

Omori R, Adams B (2011) Disrupting seasonality to control disease outbreaks: the case of koi herpes virus. J Theor Biol 271:159-165

Pearson H (2004) Carp virus crisis prompts moves to avert global spread. Nature 427:577

Perelberg A, Smirnov M, Hutoran M, Diamant A, Bejerano Y, Kotler M (2003) Epidemiological description of a new viral disease afflicting cultured Cyprinus carpio in Israel. Isr J Aquacult Bamidgeh 55:5-12

> Perelberg A, Ronen A, Hutoran M, Smith Y, Kotler M (2005) Protection of cultured Cyprinus carpio against a lethal viral disease by an attenuated virus vaccine. Vaccine 23: 3396-3403

Perelberg A, Ilouze M, Kotler M, Steinitz M (2008) Antibody response and resistance of Cyprinus carpio immunized with cyprinid herpes virus 3 (CyHV-3). Vaccine 26: 3750-3756

> Pikarsky E, Ronen A, Abramowitz J, Levavi-Sivan B and others (2004) The pathogenesis of the acute viral disease in fish induced by the carp interstitial nephritis and gill necrosis virus. J Virol 78:9544-9551

Pokorova D, Vesely T, Piackova V, Reschova S, Hulova J (2005) Current knowledge on koi herpesvirus (KHV): a review. Vet Med Czech 50:139-147

Pokorova D, Piackova V, Cizek A, Reschova S, Hulova J, Vicenova M, Vesely T (2007) Tests for the presence of koi herpesvirus (KHV) in common carp (Cyprinus carpio carpio) and koi carp (Cyprinus carpio koi) in the Czech Republic. Vet Med (Praha) 12:562-568

Raj VS, Fournier G, Rakus K, Ronsmans M and others (2011) A skin mucus of Cyprinus carpio inhibits cyprinid herpesvirus 3 binding to epidermal cells. Vet Res 42:92-100

Rakus KŁ, Irnazarow I, Adamek M, Palmeira L and others (2012) Gene expression analysis of common carp (Cyprinus carpio L.) lines during Cyprinid herpesvirus 3 infection yields insights into differential immune responses. Dev Comp Immunol 37:65-76

Rathore G, Kumar G, Swain P, Lakra WS (2009) Development of new PCR primers for detection of Koi Herpes Virus (KHV). Indian J Comp Microbiol Immunol Infect Dis 30:52-53 
Ronen A, Perelberg A, Abramowitz J, Hutoran M and others (2003) Efficient vaccine against the virus causing a lethal disease in cultured Cyprinus carpio. Vaccine 21: 4677-4684

Rosenkranz D, Klupp BG, Teifke JP, Granzow H, Fichtner D, Mettenleiter TC, Fuchs W (2008) Identification of envelope protein pORF81 of koi herpesvirus. J Gen Virol 89: 896-900

Sadler J, Marecaux E, Goodwin AE (2008) Detection of koi herpes virus (CyHV-3) in goldfish, Carassius auratus (L.), exposed to infected koi. J Fish Dis 31:71-72

Sano T, Fukuda H, Furukawa M, Hosoya H, Moriya Y (1985a) A herpesvirus isolated from carp papilloma in Japan. In: Ellis AE (ed) Fish and shellfish pathology. Academic Press, London, p 307-311

Sano T, Fukuda H, Furukawa M, Hosoya H, Moriya Y (1985b) Herpesvirus cyprini: biological and oncogenic properties. Fish Pathol 20:381-388

Sano T, Morita N, Shima N, Akimoto M (1991) Herpesvirus cyprini: lethality and oncogenicity. J Fish Dis 14: 533-543

Sano M, Ito T, Kurita J, Yanai T, Watanabe N, Miwa S, Lida $\mathrm{T}$ (2004) First detection of koi herpesvirus in cultured common carp Cyprinus carpio in Japan. Fish Pathol 39: 165-167

Sano M, Ito T, Kurita J, Miwa S, Lida T (2005) Diagnosis of Koi Herpesvirus (KHV) disease in Japan. Bull Fish Res Agency 2:59-64

Shapira Y, Magen Y, Zak T, Kotler M, Hulata G, LevaviSivan B (2005) Differential resistance to koi herpes virus (KHV)/carp interstitial nephritis and gill necrosis virus (CNGV) among common carp (Cyprinus carpio L.) strains and crossbreds. Aquaculture 245:1-11

Shimizu T, Yoshida N, Kasai H, Yoshimizu M (2006) Survival of koi herpesvirus (KHV) in environmental water. Fish Pathol 41:153-157

Soliman H, El-Matbouli M (2005) An inexpensive and rapid diagnostic method of koi herpesvirus (KHV) infection by loop-mediated isothermal amplification. Virol J 2:83

Soliman H, El-Matbouli M (2009) Immunocapture and direct binding loop mediated isothermal amplification simplify molecular diagnosis of cyprinid herpesvirus-3. J Virol Methods 162:91-95

St-Hilaire S, Beevers N, Way K, Le Deuff RM, Martin P, Joiner C (2005) Reactivation of koi herpesvirus infections in common carp Cyprinus carpio. Dis Aquat Org 67: $15-23$

St-Hilaire S, Beevers N, Joiner C, Hedrick RP, Way K (2009) Antibody response of two populations of common carp, Cyprinus carpio L., exposed to koi herpesvirus. J Fish Dis 32:311-320

Sunarto A, McColl KA, Crane MS, Sumiati T, Hyatt AD, Barnes AC, Walker PJ (2011) Isolation and characterization of koi herpesvirus (KHV) from Indonesia: identification of a new genetic lineage. J Fish Dis 34:87-101
Sunarto A, Liongue C, McColl KA, Adams MM and others (2012) Koi herpesvirus encodes and expresses a functional interleukin-10. J Virol 86:11512-11520

- Syakuri H, Adamek M, Brogden G, Rakus KŁ, Matras M, Irnazarow I, Steinhagen D (2013) Intestinal barrier of carp (Cyprinus carpio L.) during a cyprinid herpesvirus 3-infection: molecular identification and regulation of the mRNA expression of claudin encoding genes. Fish Shellfish Immunol 34:305-314

> Taylor NGH, Dixon PF, Jeffery KR, Peeler EJ, Denway KL, Way K (2010) Koi herpesvirus: distribution and prospects for control in England and Wales. J Fish Dis 33:221-230

Taylor NGH, Norman RA, Way K, Peeler EJ (2011) Modelling the koi herpesvirus (KHV) epidemic highlights the importance of active surveillance within a national control policy. J Appl Ecol 48:348-355

Tu C, Weng MC, Shiau JR, Lin SY (2004) Detection of koi herpesvirus in koi Cyprinus carpio in Taiwan. Fish Pathol 39:109-110

> Uchii K, Matsui K, Iida T, Kawabata Z (2009) Distribution of the introduced cyprinid herpesvirus 3 in a wild population of common carp, Cyprinus carpio L. J Fish Dis 32:857-864

- Uchii K, Telschow A, Minamoto T, Yamanaka H, Honjo MN, Matsui K, Kawabata Z (2011) Transmission dynamics of an emerging infectious disease in wildlife through host reproductive cycles. ISME J 5:244-251

van Beurden SJ, Bossers A, Voorbergen-Laarman MH, Haenen OL and others (2010) Complete genome sequence and taxonomic position of anguillid herpesvirus 1. J Gen Virol 91:880-887

Waltzek TB, Kelley GO, Stone DM, Way K and others (2005) Koi herpesvirus represents a third cyprinid herpesvirus (CyHV-3) in the family Herpesviridae. J Gen Virol 86: 1659-1667

Waltzek TB, Kelley GO, Alfaro ME, Kurobe T, Davison AJ, Hedrick RP (2009a) Phylogenetic relationships in the family Alloherpesviridae. Dis Aquat Org 84:179-194

> Waltzek TB, Kurobe T, Goodwin AE, Hedrick RP (2009b) Development of a polymerase chain reaction assay to detect cyprinid herpesvirus 2 in goldfish. J Aquat Anim Health 21:60-67

Whalen G (2011) DNR detects koi herpesvirus in Silver Lake fish kill. Michigan Department of Natural Resources, Newberry, MI

> Yoshino M, Watari H, Kojima T, Ikedo M (2006) Sensitive and rapid detection of Koi herpesvirus by LAMP method. Fish Pathol 41:19-27

- Yoshino M, Watari H, Kojima T, Ikedo M, Kurita J (2009) Rapid, sensitive and simple detection method for koi herpesvirus using loop mediated isothermal amplification. Microbiol Immunol 53:375-383

Yuasa K, Kurita J, Kawana M, Kiryu I, Oseko N, Sano M (2012) Development of mRNA-specific RT-PCR for the detection of koi herpesvirus (KHV) replication stage. Dis Aquat Org 100:11-18

Submitted: November 27, 2012; Accepted: May 6, 2013

Proofs received from author(s): June 28, 2013
Editorial responsibility: Mark Crane,

Geelong, Victoria, Australia 